\title{
Endothelial Barrier Function under Laminar Fluid Shear Stress
}

\author{
Jochen Seebach, Peter Dieterich, Fei Luo, Hermann Schillers, Dietmar Vestweber, \\ Hans Oberleithner, Hans-Joachim Galla, and Hans-Joachim Schnittler
}

Institut für Biochemie (JS, H-JG), WWU-Münster, Münster, Rechenzentrum der Universität Würzburg (PD), Zentrum

für Molekularbiologie der Entzündung (DV) and Institut für Physiologie (HS, HO), WWU-Münster, and Institut für Physiologie (FL, H-JS), Dresden, Germany

\begin{abstract}
SUMMARY: It has been suggested that increasing levels of shear stress could modify endothelial permeability. This might be critical in venous grafting and in the pathogenesis of certain vascular diseases. We present a novel setup based on impedance spectroscopy that allows online investigation of the transendothelial electrical resistance (TER) under pure laminar shear stress. Shear stress-induced change in TER was associated with changes in cell motility and cell shape as a function of time (morphodynamics) and accompanied by a reorganization of catenins that regulate endothelial adherens junctions. Confluent cultures of porcine pulmonary trunk endothelial cells typically displayed a TER between 6 and $15 \Omega \mathrm{cm}^{2}$ under both resting conditions and low shear stress levels $\left(0.5 \mathrm{dyn} / \mathrm{cm}^{2}\right)$. Raising shear stress to the range of 2 to $50 \mathrm{dyn} / \mathrm{cm}^{2}$ caused a transient $2 \%$ to $15 \%$ increase in TER within 15 minutes that was accompanied by a reduction in cell motility. Subsequently, TER slowly decreased to a minimum of $20 \%$ below the starting value. During this period, acceleration of shape change occurred. In the ensuing period, TER values recovered, reaching control levels within hours and associated with an entire deceleration of shape change. A heterogeneous distribution of $\alpha-, \beta$-, and $\gamma$-catenin, main components of the endothelial adherens type junctions, was also observed, indicating a differentiated regulation of shear stress-induced junction rearrangement. Additionally, catenins were partly colocalized with $\beta$-actin at the plasma membrane, indicating migration activity of these subcellular parts. Shear stress, even at peak levels of $50 \mathrm{dyn} / \mathrm{cm}^{2}$, did not cause intercellular gap formation. These data show that endothelial monolayers exposed to increased levels of laminar shear stress respond with a shear stress-dependent regulation of permeability and a reorganization of junction-associated proteins, whereas monolayer integrity remains unaffected. (Lab Invest 2000, 80:1819-1831).
\end{abstract}

$E$ ndothelial cells of the arterial and venous system display different phenotypes, which are thought to be largely influenced by hemodynamic forces. Shear stress, in particular, changes endothelial morphology in vivo and in cell culture models. Endothelial cells of the venous system are polygonal in shape and do not display a preferred orientation. In the arterial system, endothelial cells are elongated and align in the direction of flow. Additionally, endothelial cells of veins transposed into the arterial system undergo a shape change resulting in cellular alignment (Flaherty et al, 1972; Langille and Adamson, 1981; Levesque et al, 1986; Nerem, 1992; Okano and Yoshida, 1993; Yoshida and Sugimoto, 1996). In vitro, cultured endothelial cells normally display a venous-like morphology under static conditions, even when derived from the arterial system (Remuzzi et al, 1984). Endothelial cells exposed to hemodynamic forces have a more arteriallike morphology (Dewey et al, 1981; Eskin et al, 1984). They also have an increased expression of structural

Received July 3, 2000.

This work was supported by the Graduiertenkolleg "Membranproteine: Signalerkennung, Signaltransfer und Stofftransport" DFG Gc 233/1-97 and DFG Grants SCHN 430/2-4 and SCHN 430/1-1.

Address reprint requests to: Dr. Hans-Joachim Schnittler, Institut für Physiologie, Fiedlerstrasse 42, D-01307 Dresden, Germany. Fax: 49351 4586301;E-mail:Hans.Schnittler@mailbox.tu-dresden.de components, such as actin filament stress fibers (De Chastonay et al, 1983; Franke et al, 1984; Gabbiani et al, 1983; Schnittler et al, 1989; Wong et al, 1983) and of vimentin intermediate filaments (Schnittler et al, 1998). Both filamentous systems are thought to increase the ability of endothelial cells to withstand mechanical forces such as shear stress and wall distension.

Detailed quantitative analyses of shear stress-induced morphologic changes as a function of time (morphodynamics) showed that endothelial cells within confluent cultures pass through different phases (Dieterich et al, 2000). Phase I corresponds to resting conditions or very low shear stress values, and is characterized by random cell orientation, polygonal cell shape, and a moderate mean migration (locomotion) of the cells (ie, cell centers) that is associated with extended zigzag movements (fluctuations) around the mean locomotion trajectories. Onset of shear stress causes a rapid down-regulation of the fluctuations and a transient increase in locomotion (phase II). After a lag period, cells begin to align (phase III). Finally, cell elongation occurs within hours (phase IV). Morphodynamics of cells within a confluent culture under shear stress require at least a sophisticated regulation of cell-to-cell adhesion, to allow motile activity of the cells relative to each other. 
Besides morphodynamic characterization, a shear stress-induced increase in permeability has been shown in cell culture models (DePaola et al, 1992; Waters, 1996; Waters et al, 1996). However, in situ, increased permeability occurs within sites of low shear stress and flow separation. Arteriosclerotic lesions are typically found at those locations (Caro et al, 1969; Caro and Nerem, 1973; Ku et al, 1985; Yoshida et al, 1995). In contrast, endothelial adaptation to shear stress (eg, cardiac bypass) and the underlying morphodynamics might be associated with changes in permeability because a rearrangement of cell-to-cell junctions is required for shape change.

Endothelial cells do not display a specific order of junctions. They consist of an extended adherens junction zone in which gap junctions and strands of tight junctions are morphologically inserted (Franke et al, 1988). The vascular endothelial cadherin (VE-cadherin) and catenin complex is a main component of the endothelial adherens-type junctions that are commonly found in the endothelium of all vascular segments (for review, see Dejana, 1997; Schnittler and Feldmann, 1999). VE-cadherin and the associated proteins $\alpha^{-}, \beta-$, and $\gamma$-catenin, are connected to the cytoskeleton. This interaction is important for control of endothelial permeability and contact inhibition (for review, see Dejana, 1996; Dejana et al, 1999; Lampugnani and Dejana, 1997). Chinese hamster ovary cells transfected with C-terminal-truncated VE-cadherin, which is not able to bind catenins, did not respond with changes in paracellular permeability after stimulation (Navarro et al, 1995). Thus, it was suggested that catenins are crucially involved in the regulation of cell-to-cell adhesion properties in endothelial cells. $\beta$-catenin and $\gamma$-catenin bind directly to cadherins, whereas $\alpha$-catenin links the cadherin $/ \beta$ - catenin $/ \gamma$ catenin complex directly or indirectly via $\alpha$-actinin to actin filaments (Knudsen et al, 1995; Rimm et al, 1995). $\beta$-catenin is involved in Wnt growth factor signaling pathways. $\gamma$-catenin is thought to be required for junction maturation (Lampugnani et al, 1995), to maintain endothelial integrity under the load of fluid shear stress (Schnittler et al, 1997), and to maintain integrity of cardiomyocytes in mice (Ruiz et al, 1996). The role of $\alpha$-catenin has not been addressed in detail, but treatment of cells with pervanadate caused a loss of $\alpha$-catenin from the cadherin/ catenin complex in E-cadherin-expressing K562 cells (Ozawa and Kemler, 1998). Additionally, there is evidence that the extracellular domain of cadherins as well as $\mathrm{N}$-glycans of VE-cadherin contribute to the organization of the complex at the junctions (Geyer et al, 1999; Yap et al, 1997).

Because of the importance of shear stress on the development of arterial and venous phenotypes and the importance of cell-to-cell junctions in maintaining endothelial integrity, we investigated changes in barrier function during the early phases of endothelial shear stress adaptation. Here, we introduce a novel setup that allows the determination of electrical resistance of cultured cell monolayers by impedance spectroscopy under fluid shear stress. Furthermore, we show that endothelial cell monolayers respond with a shear stress-dependent graduated regulation of transendothelial electrical resistance (TER), whereas monolayer integrity is maintained. These changes correlated with the shear stress-induced morphodynamic activity of cells and a characteristic reorganization of adherens junction-associated proteins.

\section{Results}

\section{TER of Porcine Endothelial Cells}

Porcine endothelial cells isolated from pulmonary trunks (PSEC) were seeded onto round glass slides covered with gold electrodes, as illustrated in Figure 1. Cultures were inserted into the sample mounting support of the cone and plate rheological units. The rotating cone produces defined laminar shear stress levels between 0 and $200 \mathrm{dyn} / \mathrm{cm}^{2}$. The setup allows phase-contrast observation and impedance analysis of a cell monolayer under laminar shear stress. The thickness of the electrodes (approximately $0.15 \mu \mathrm{m}$ ) is below the height of the cells (between 2 and $3 \mu \mathrm{m}$ ), thus, the electrodes do not disturb the laminar flow profile.

Detailed discussions of impedance analysis of cell monolayers cultured on gold electrodes have been given previously (Giaever and Keese, 1984, 1991; Wegener et al, 1996, 1999). The theoretical model used in this paper to describe the electrical properties of the cell-covered electrodes was recently introduced (Wegener et al, 1999) and is illustrated in Figure 2, together with characteristic impedance spectra obtained from measurements in the absence and presence of a confluent endothelial cell monolayer. We measured the impedance magnitude $|Z|$, which equals the ratio between the amplitude of an alternating voltage $\left(U_{0}\right)$ applied to the system and the amplitude of the associated alternating current $\left(\mathrm{I}_{0}\right)$ in the frequency range of $10 \mathrm{~Hz}$ to $1 \mathrm{MHz}$. In absence of a cell monolayer, the impedance behavior of the system can be described by a series connection of an ohmic resistor, representing the resistance of the medium $\left(R_{\text {bulk }}\right)$, and a constant phase element, which represents the electrode. In the frequency range between $10 \mathrm{kHz}$ and $1 \mathrm{MHz}$, the overall impedance of the system is determined by the frequency-independent ohmic resistor, whereas at lower frequencies the increasing impedance of the constant phase element predominates. The presence of a cell monolayer completely covering the electrodes significantly increases the impedance in the range between $10^{3} \mathrm{~Hz}$ and $3 \times$ $10^{5} \mathrm{~Hz}$ (Fig. 2). Depending on the applied frequency, the alternating current may flow through the intercellular junctions and/or may traverse the monolayer transcellularly via the plasma membranes. The paracellular path has properties of an ohmic resistor (ie, TER) and is used to determine the tightness of cell-tocell contacts. Depending on the endothelial cell type, TER values of a confluent monolayer may range from $3 \Omega \mathrm{cm}^{2}$ up to more than $1000 \Omega \mathrm{cm}^{2}$ (Hoheisel et al, 1998; Wegener et al, 1996, 1999). The transcellular 


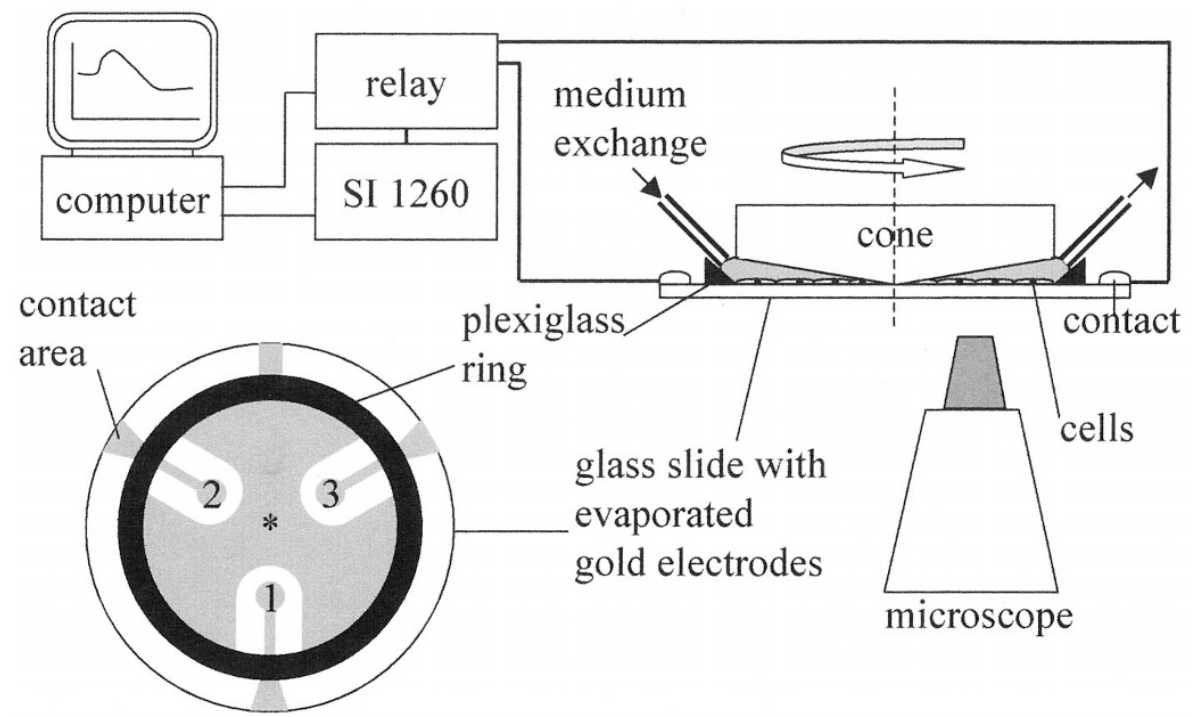

\section{Figure 1.}

Scheme of the experimental setup. A cone and plate rheological in vitro system was used to generate defined levels of shear stress on cultured cells. Gold electrodes evaporated onto the surface of glass slides were connected to a computer-controlled impedance analyzer via a relay. Continuous medium exchange was performed through capillaries. The cell layer could be examined by a phase-contrast microscope during shear stress application and images (eg, with time-lapse recording) were recorded automatically. *: counter electrode; 1, 2, 3: measuring electrodes.

path, however, is characterized by the membrane capacitance (see insert in Fig. 2). The specific capacitance for a plasma membrane is close to $1 \mu \mathrm{F} / \mathrm{cm}^{2}$ for most cell types (Cole, 1972). Thus, with both apical and the basolateral membranes, the theoretical capacitance value for a confluent cell monolayer is approximately $0.5 \mu \mathrm{F} / \mathrm{cm}^{2}$ (Wegener et al, 1999). For the described model to be valid, the cell layer must be confluent and have relatively homogenous electrical properties. Subconfluent cultures or monolayers with large gaps between the cells will still influence the impedance spectra (Janshoff et al, 1996), but if parts of the electrode are uncovered the model can no longer sufficiently describe the electrical properties of

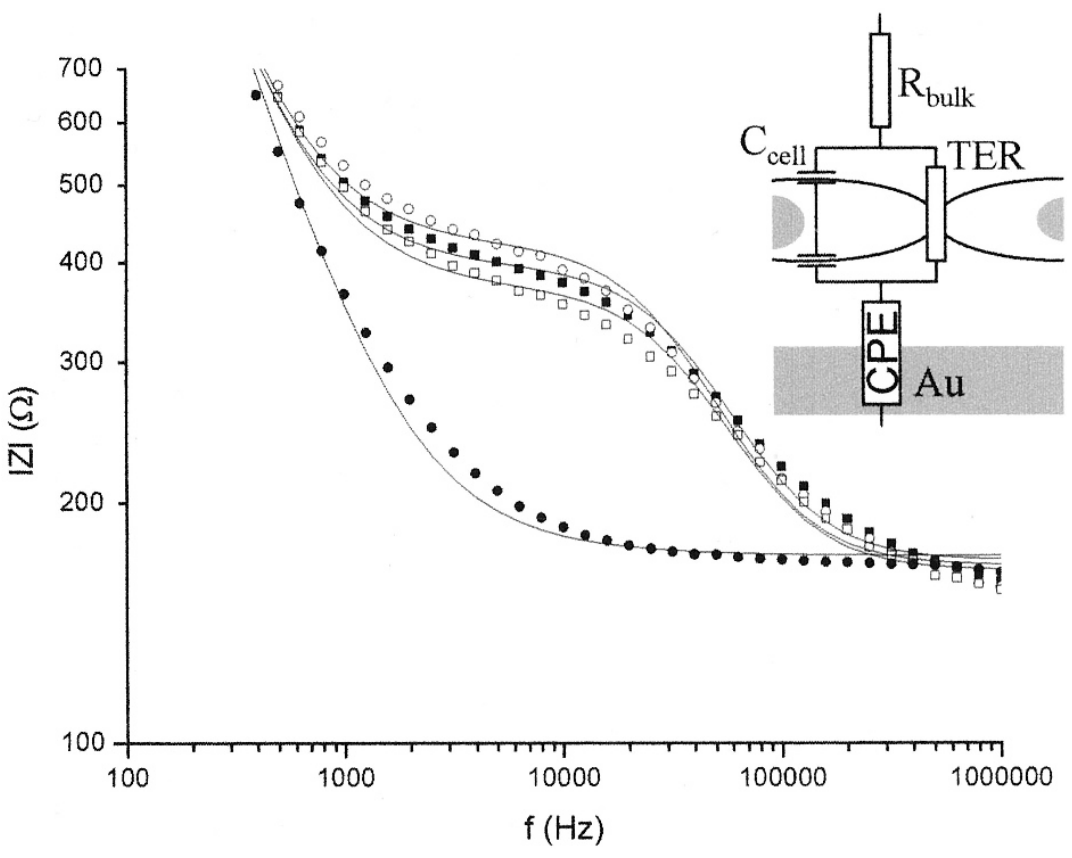

Figure 2.

Impedance spectra of individual time points obtained in the frequency range between $10 \mathrm{~Hz}$ and $1 \mathrm{MHz}$ of a cell-free electrode (-) and an electrode covered with cells under resting conditions $(\square)$, after shear stress exposure $\left(20 \mathrm{dyn} / \mathrm{cm}^{2}\right)$ for 20 minutes $(\bigcirc)$ and 6 hours ( $\square$ ). The solid lines represent the results of the fits of the corresponding equivalent circuit shown in inset. $R_{\text {bulk }}$ represents the ohmic resistance of the culture medium; $C_{c e l l}$ the capacitance of the cells; TER (transendothelial electrical resistance) represents the paracellular resistance; CPE (constant phase element) represents the electrode/electrolyte interface; and $A u$ represents the gold electrode. Note that the different levels of $|\mathrm{Z}|$ at the plateau indicate different TER in the culture. 
the monolayer. This is apparent from distinct differences between the form of the measured and the calculated impedance spectra. Under these conditions, the model parameters loose their discussed meanings and the capacitance values become artificially higher than the expected value of approximately $0.5 \mu \mathrm{F} / \mathrm{cm}^{2}$. This disparity can be used formally as an indicator for gaps between the cells. Characteristic spectra are depicted in Figure 2, with different impedance values under resting conditions $(\nu)$ and after measured periods of shear stress application. For frequencies between $10^{3} \mathrm{~Hz}$ and $3 \times 10^{5} \mathrm{~Hz}$, fluid shear stress applied over 20 minutes increased IZI, whereas after 6 hours a decrease in $|Z|$ was observed (Fig. 2).

\section{TER under Fluid Shear Stress}

Confluent cultures of PSEC with TER values between 6 and $15 \Omega \mathrm{cm}^{2}$ were inserted into the rheological units (Fig. 1) and medium was exchanged continuously. Cells were exposed to $0.5 \mathrm{dyn} / \mathrm{cm}^{2}$ for at least 1 hour. Shear stress levels of $0.5 \mathrm{dyn} / \mathrm{cm}^{2}$ had no significant effect on the TER. Onset of higher shear stress levels (between $2 \mathrm{dyn} / \mathrm{cm}^{2}$ and $50 \mathrm{dyn} / \mathrm{cm}^{2}$ ) caused an initial increase in TER after a lag of approximately 2 to 4 minutes. Within approximately 10 minutes, the shear stress-induced increase in TER reached a transient maximum of up to $15 \%$ at $50 \mathrm{dyn} / \mathrm{cm}^{2}$. This was followed by a decrease in TER, which typically reached a minimum of $5 \%$ to $20 \%$ below the initial value. A continuous but slow increase in TER typically followed within the next hours. A characteristic experiment is shown in Figure $3 a$, in which a sheer stress level of $10 \mathrm{dyn} / \mathrm{cm}^{2}$ was applied to confluent endothelial cells for 10 hours. Additionally, the capacitance and the structural index (SI) of the cell layer were determined (Fig. 3, b and c). Control cells exposed to $0.5 \mathrm{dyn} / \mathrm{cm}^{2}$ of shear stress sometimes displayed a slow decrease in TER but did not show shear stressinduced characteristic changes (Fig. 3a). Interruption of shear stress after 10 hours resulted in an approximately $10 \%$ to $15 \%$ sudden decrease in TER within minutes (Fig. 4a). Treatment of cells with $3 \mathrm{mmol} / \mathrm{l}$ of EGTA, which leads to calcium depletion $\left(\left[\mathrm{Ca}^{2+}\right]<10^{-7}\right.$ $\mathrm{mol} / \mathrm{l})$, triggered a rapid decrease in TER to approximately 55\% (Fig. 4a). Because only calciumdependent cell adhesion molecules such as VEcadherin but not calcium-independent adhesion molecules such as platelet endothelial cell adhesion molecule-1 (PECAM-I) dissociate from intercellular junctions with EGTA treatment (Ayalon et al, 1994; Lampugnani et al, 1995; Schnittler et al, 1997), it is reasonable to assume that the remaining molecules partially maintain the TER and do not lead to a drop to zero. Under physiologic levels of shear stress, capacitance remained constant (Fig. 3b) even when the shear stress was interrupted. However, treatment of cells with EGTA caused a slight increase in capacitance, from $0.45 \mu \mathrm{F} / \mathrm{cm}^{2}$ up to approximately 0.65 $\mu \mathrm{F} / \mathrm{cm}^{2}$ (Fig. 4b).

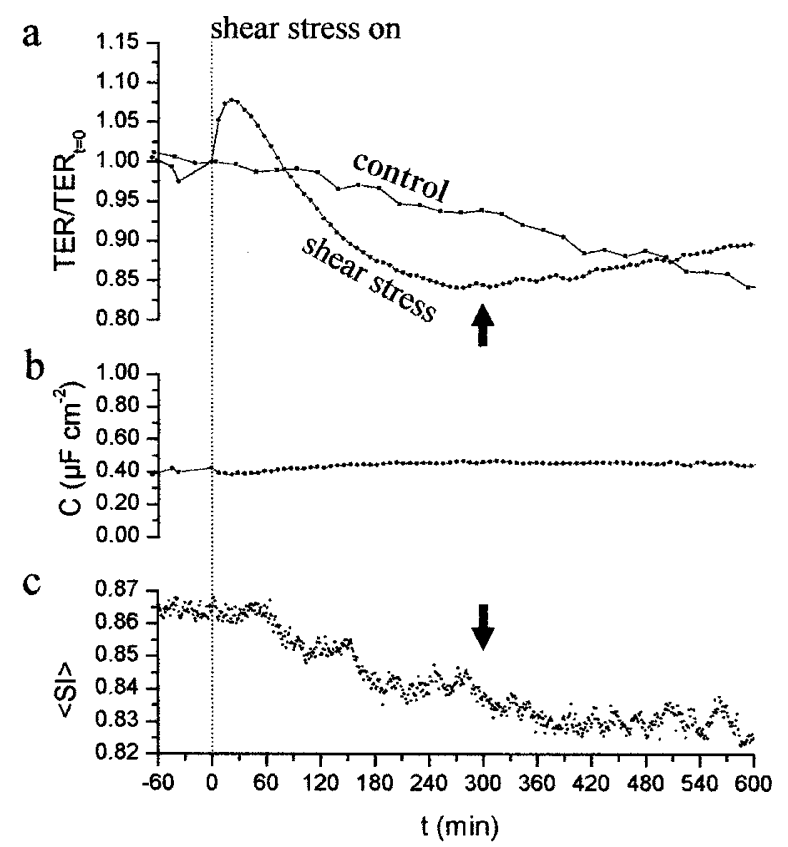

Figure 3.

Time courses for $(a)$ the TER, $(b)$ the capacitance, $C$, and $(c)$ the structural index $(S I)$ of confluent endothelial cell monolayers. Shear stress of $10 \mathrm{dyn} / \mathrm{cm}^{2}$ (-) leads to characteristic changes in TER (a) whereas the TER of the control cells $\left(\mathbf{\square}, 0.5 \mathrm{dyn} / \mathrm{cm}^{2}\right)$ shows only a slight drift over 10 hours. The capacitance of the cell layer exposed to shear stress remains constant $(b)$ indicating an intact monolayer. The change in $\mathrm{SI}(c)$ begins approximately 1 hour after the onset of shear stress and is accompanied by a transient decrease in TER. At 300 minutes, TER values start to recover (a, arrow), associated with flattening of the SI to a more or less constant level (c,arrow indicates the beginning of the flattening) indicating reduced cellular morphodynamics.

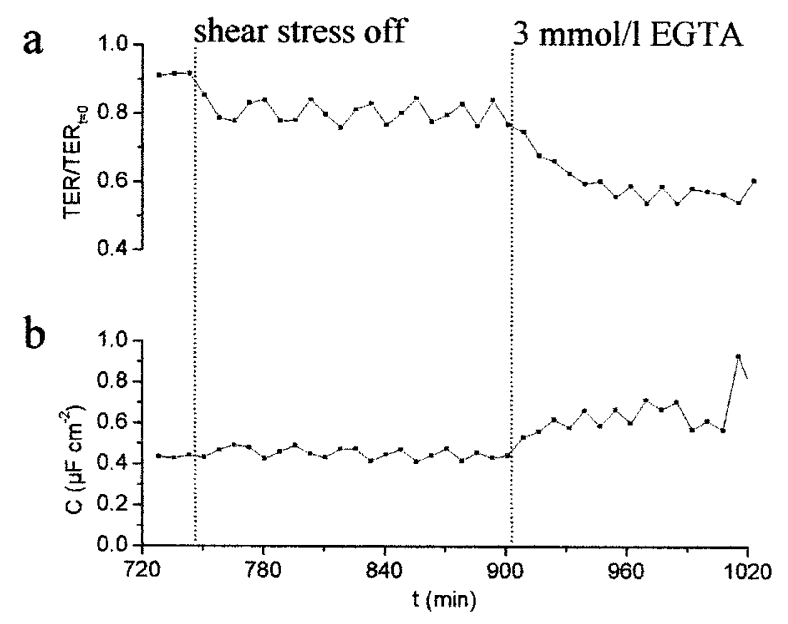

Figure 4.

Time courses of the TER (a) and capacitance, $C(b)$ after treatment of endothelial cells with shear stress at $10 \mathrm{dyn} / \mathrm{cm}^{2}$ for approximately 10 hours (compare with Figure 3) and EGTA. After 745 minutes, the shear stress was turned off, which decreased the TER, but capacitance remained constant. Application of $3 \mathrm{mmol} / \mathrm{l}$ of EGTA caused a further decrease in TER.

\section{Shear Stress-Induced Initial Increase in TER}

We next focused on the flow-dependent initial increase in TER. We investigated whether the increase in TER was dependent on the shear stress level applied and whether it was reversible. The same 
confluent endothelial cell cultures were exposed to periods (24 minutes, corresponding to 10 impedance spectra) of shear stress levels in the range of 2 to 50 dyn $/ \mathrm{cm}^{2}$. Each period was interrupted by $24-$ minute periods of a low shear stress level $\left(0.5 \mathrm{dyn} / \mathrm{cm}^{2}\right)$. This low level did not cause changes in endothelial permeability or cellular structure. As shown in Figure 5, a and $b$, each level of shear stress initiated a characteristic time course of TER changes. Whereas shear stress levels of $5 \mathrm{dyn} / \mathrm{cm}^{2}$ induced only a $5 \%$ increase in TER within 18 to 20 minutes, levels up to $50 \mathrm{dyn} / \mathrm{cm}^{2}$ displayed an approximately $15 \%$ increase in TER within 10 minutes. Changes in TER were also correlated with changes in fluctuations and SI (Fig. 5, c and $\mathrm{d}$, see below). A detailed analysis of the shear stressdependent changes in TER is shown in Figure 6. In addition to data already shown in Figure 5, decreasing shear stress levels were applied to the same culture. Shear stress levels of $2 \mathrm{dyn} / \mathrm{cm}^{2}$ initially increased the TER, even after several periods of higher shear stress. When changes in TER were plotted as a function of time, a shear stress-dependent maximum was observed (Fig. 6a). This was also illustrated by plotting the quotient $\mathrm{TER}_{\max } / \mathrm{TER}_{\mathrm{o}}$ as a function of the shear
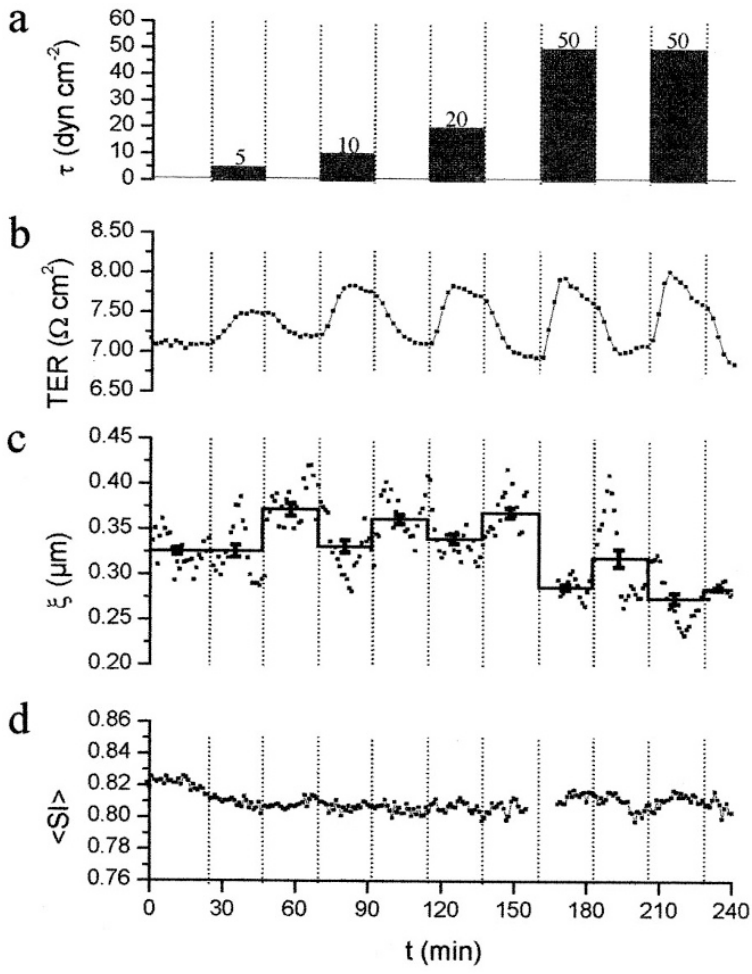

Figure 5.

Correlation of periodically applied shear stress levels (a) with TER $(b)$, fluctuations $(c)$ and $S I(d)$. A reversible, shear stress-dependent increase in TER $(b)$ was observed within each period and was followed by a slight decrease in TER. Interruption of shear stress caused a rapid decrease. Changes in the TER time course roughly correlated with the initial decreases in cellular fluctuations, , (c) under shear stress, followed by increases after shear stress interruption. The solid line represents the average fluctuation within the time interval. Error bars indicate the corresponding standard error. The $\mathrm{SI}(d)$ did not show marked differences because of the shortness of the periods of shear stress application. Interruptions of the curves in $(c)$ and $(d)$ are due to nonanalyzable images. stress level (Fig. 6b). Furthermore, the period required to reach a particular maximum was inversely correlated with the applied flow (Fig. 6c). Reduction of the shear stress to $0.5 \mathrm{dyn} / \mathrm{cm}^{2}$ caused a decrease in TER within 5 to 10 minutes. These data confirm the concept that the observed increases in TER are directly dependent on the presence of shear stress. Moreover, there was a graduated TER response that followed a characteristic time course. Thus, a quick and graduated regulation of cell-to-cell junctions is required.

\section{Correlation of Shear Stress-Induced Changes in TER with Morphodynamic Parameters}

Recently we described a novel rheological setup and novel software, also used in the present study, that can be used to analyze morphodynamic parameters (Dieterich et al, 2000). Morphodynamics are defined as changes in cell motility, cell orientation, and cell elongation, as functions of time. Cell motility, in particular, was discovered to be composed of two phenomena. The onset of shear stress caused both a decrease of random cellular zigzag movement (fluctuations of cell centers), typically observed under resting conditions, and an increase in directed cell locomotion. Additionally, heterogeneous behaviors were observed for individual endothelial cells within confluent monolayers. These data suggest that cell-to-cell junctions might significantly influence the motility of endothelial cells under shear stress. Thus, we correlated shear stressinduced changes in TER with changes in SI and changes in migration activity (fluctuations). Timelapse recording of phase contrast images was performed during shear stress exposure on the same cells that are shown in Figures 3, 5, and 6. The SI was used to quantitatively describe the cell shape. A perfectly round cell is characterized by a SI of 1 , whereas elongated cells have lower values. Shear stress leads to cell elongation and this process may require more than 24 hours (Levesque and Nerem, 1985). In Figure 3c, the shear stress-induced change in $\mathrm{SI}$ is plotted as a function of time. After a delay of approximately 1 hour, SI decreased continuously within 4 hours and was accompanied by a decrease in TER. Subsequently, the decrease of SI was less pronounced and the TER began to recover. Although changes in cellular shape may not have been completed within the 10 hour observation period, shape change requires a reorganization of cell-to-cell junctions and thus may lead to a reduced TER. Shear stress-induced changes in TER also seem to be related to changes in cell motility. We recently investigated the change in cell motility under fluid shear stress and found that mean velocities of cell locomotion increased whereas spatial fluctuations around the mean cell paths decreased (Dieterich et al, 2000). The periodically applied shear stress levels caused characteristic changes in TER that directly corresponded with changes in fluctuations (Fig. 5, a, b, and c). Because of the shortness of the time periods when the shear stress was applied, the SI did not change significantly (Fig. 5d). 

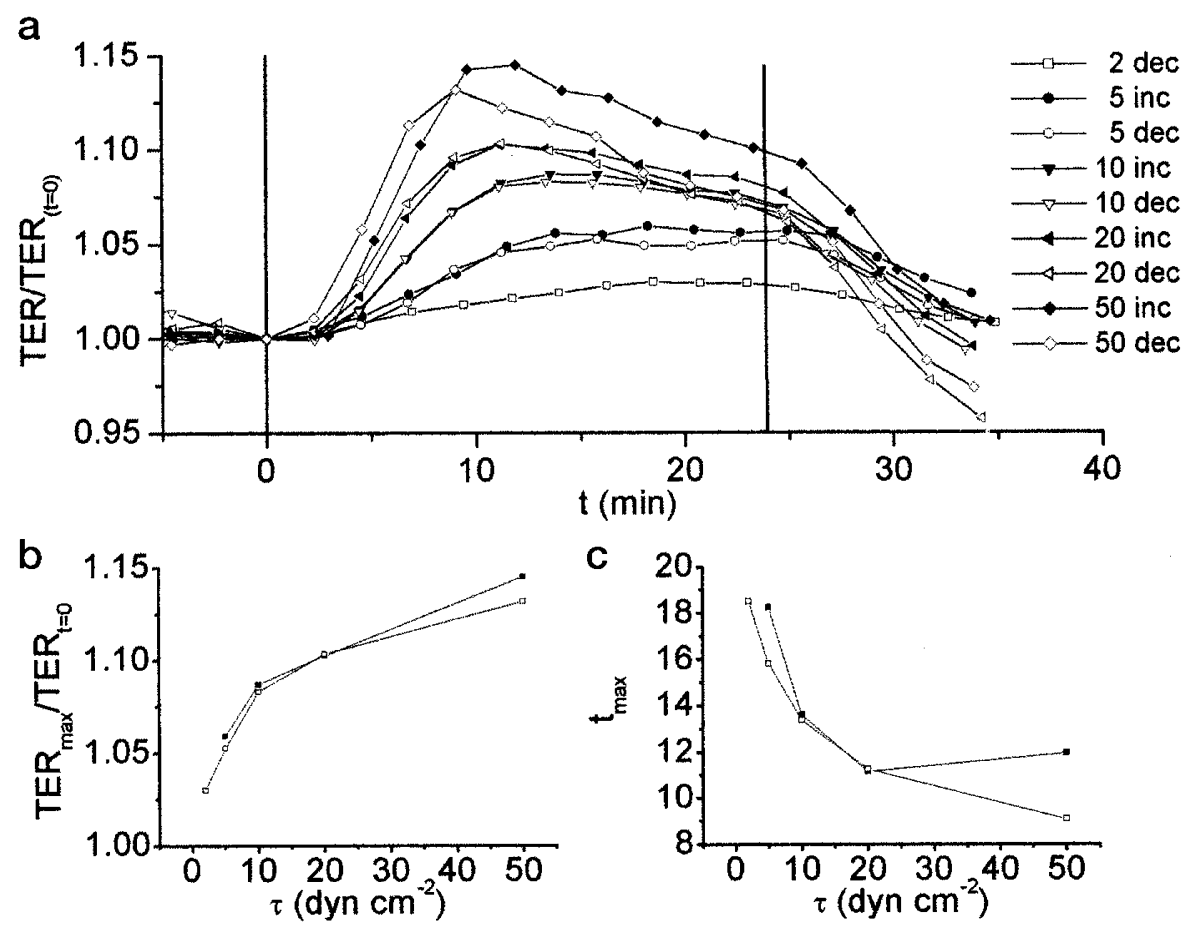

Figure 6.

Shear stress-dependent change in TER. a, Different levels of shear stress were applied to the same confluent culture of porcine endothelial cells (PSEC) for 24-minute periods and subsequently interrupted for 24 minutes, as indicated. The normalized TER is plotted as a function of time. Filled symbols represent shear stress levels that were applied in an increased order (inc) from 5 to $50 \mathrm{dyn} / \mathrm{cm}^{2}$. Open symbols represent shear stress levels applied in a decreased order (dec). $b$, The maximal increase in TER is strongly dependent on shear stress. $c$, The time needed to reach the maximal TER inversely correlated with the shear stress level applied.

\section{Distribution of Catenins under Fluid Shear Stress}

Experiments on PSEC revealed a shear stress-dependent change in physiologic parameters such as TER, cell motility, and Sl. We further investigated the morphologic appearance of cell-to-cell junctions by immunocytochemical assays for catenins, which are thought to be causally involved in regulation of cellto-cell junctions. We used peak shear stress levels of $50 \mathrm{dyn} / \mathrm{cm}^{2}$ to uncover potential disturbances to the catenin distribution under shear stress. PSEC exposed to shear stress levels up to $50 \mathrm{dyn} / \mathrm{cm}^{2}$ typically developed stress fibers (data not shown) as described for human umbilical vein endothelial cells (Franke et al, 1984). After 10 minutes of shear stress exposure, PSEC did not display marked differences in the distribution of $\gamma-, \beta$-, and $\alpha$-catenin compared with untreated controls (Fig. 7, a and $\mathrm{a}_{1}$ ). However, after 1 hour, some indications of heterogeneity in the immunofluorescence pattern were observed (Fig 7, b and $b_{1}$ ). After 3 to 5 hours, wide overlapping areas and small continuous bands only partly interrupted along the cell-to-cell junctions were observed. By this time, cells had started to elongate (Fig. 7, c and $\mathrm{C}_{1}$ ). No gap formation was observed after 5 hours, at the time when the TER usually had reached its minimum. Higher magnification revealed the continuity of the cell-to-cell junctions and the presence of both $\beta$ - and $\gamma$-catenin (Fig. 8, a and $a_{1}$ ) and $\alpha$-catenin (data not shown). Additionally, under resting conditions we observed a catenin superstructure already described for VE-cadherin in human endothelial cells (Geyer et al,
1999) in PSEC (Fig. 8c). Shear stress exposure caused a reduced extension of this structure (Fig. 8).

Based on the heterogeneity observed in motility between adjacent cells (Dieterich et al, 2000), we assumed that small nonoverlapping areas of catenin immunoreactivity represented areas of cell motility. Therefore, we investigated the expression of $\beta$-actin, which occurs at leading edges of individual nonconfluent cells (Hoock et al, 1991). A colocalization was observed between $\beta$-catenin (Fig. 9, a and b) and $\beta$-actin (Fig. 9, $a_{1}$ and $b_{1}$ ) at junctions of small catenin bands. In these areas, stress fiber formation was rare, whereas in areas displaying overlapping cell-to-cell junctions, stress fiber formation was prominent (Fig. 9, $b$ and $b_{1}$ ). These data show a heterogeneous reorganization of cell-to-cell junctions under shear stress within the same cells. Consistent with only small variations in transendothelial resistance during shear stress exposure, we did not observe formation of intercellular gaps or a loss of catenins from the junctions under physiologic levels of laminar fluid shear stress under $50 \mathrm{dyn} / \mathrm{cm}^{2}$ within the investigated periods of time.

\section{Discussion}

We described a novel experimental setup to monitor endothelial barrier function under defined levels of laminar fluid shear stress. We investigated shear stress-induced changes in TER and found a correlation with cellular morphodynamics. Catenins, a major 


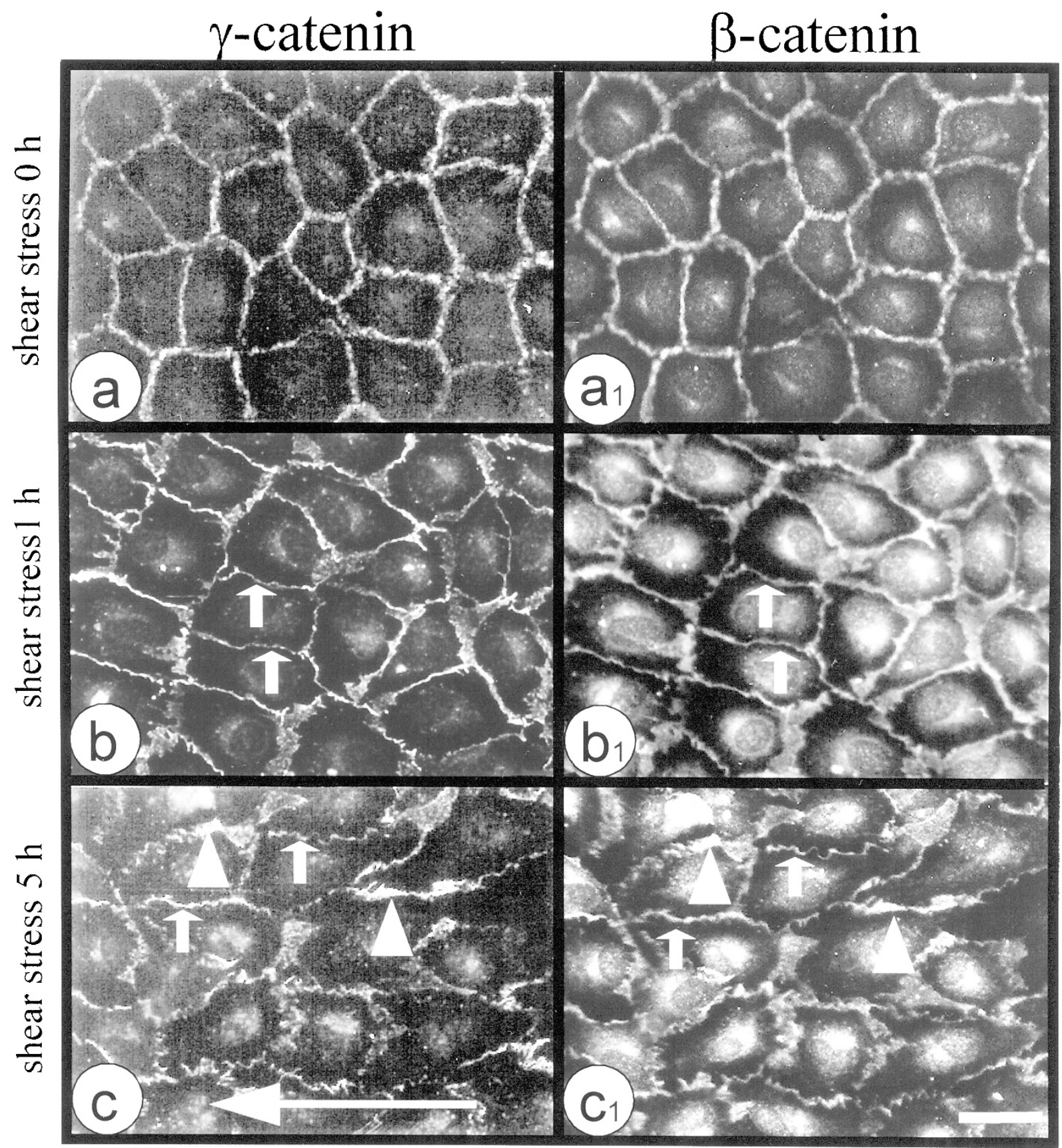

Figure 7.

Fate of catenins under a $50 \mathrm{dyn} / \mathrm{cm}^{2}$ load of fluid shear stress. Control cells $\left(a, a_{1}\right)$ and cells exposed to shear stress for 1 hour $\left(b, b_{1}\right)$ and 5 hours $\left(c, c_{1}\right)$ were double-labeled as indicated with a monoclonal antibody to $\gamma$-catenin $(a$ to $c)$ and a polyclonal antibody to $\beta$-catenin $\left(a_{1}\right.$ to $\left.c_{1}\right)$. Note that shear stress causes a time-dependent reorganization of catenins at the junctions, displaying overlapping areas of cell-to-cell junctions (arrowheads) alternating with thin bands of reduced immunofluorescence intensity (arrows). Bar, $50 \mu \mathrm{m}$.

component of adherens-type junctions, were also redistributed.

\section{Endothelial Cells Display a Shear Stress-Dependent Change in TER}

Increases in TER were strongly dependent on shear stress and completely reversible even with repeated applications to the same cells (Fig. 5). Additionally, a characteristic decrease followed the initial increase in TER. The molecular mechanisms underlying these characteristic changes remain unknown. However, there are several possibilities by which regulation can be mediated. Nucleotides such as ATP, ADP, and UTP have been shown to reduce endothelial permeability (Noll et al, 1999). Shear stress causes a release of ATP from endothelial cells, thus this might be a mechanism leading to an initial increase in TER through activation of purinergic receptors (Burnstock, 1999; Shen et al, 1992, 1993), which might induce changes in barrier function. Therefore, we added ATP to our cell cultures 

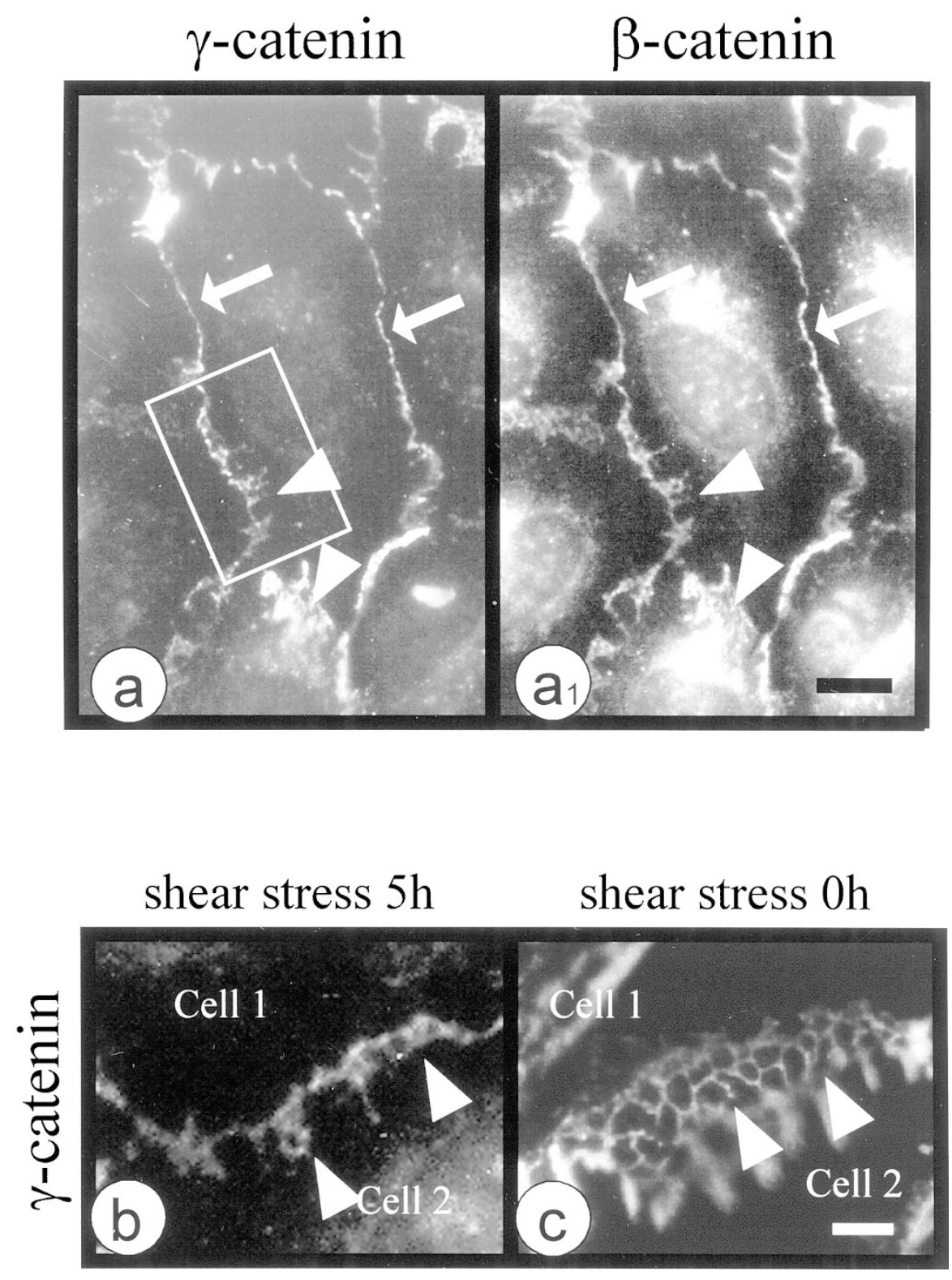

Figure 8.

High magnification of endothelial cells after 5 hours of $50 \mathrm{dyn} / \mathrm{cm}^{2}$ shear stress exposure $\left(a, a_{1}\right.$, and $\left.b\right)$. Cells are labeled by antibodies as indicated. Within the same cell, overlapping areas of cell-to-cell junctions (arrowheads) alternate with small bands facing the junctions (arrows). Endothelial cells displaying catenin superstructures $(c)$ that are partially maintained under shear stress $\left(b\right.$, arrowheads). Bars, $\left(a, a_{1}\right): 15 \mu \mathrm{m} ;(b, c): 2.5 \mu \mathrm{m}$.

and found a dose-dependent increase in TER that was saturated at $10 \mu \mathrm{mol} / \mathrm{l}$ of ATP (data not shown). Moreover, evidence indicates that nitric oxide (NO) decreases endothelial permeability (Suttorp et al, 1996; van Hinsbergh, 1997) and shear stress causes activation of NO synthase (Yuan et al, 1992). Additionally, mechanisms acting via cAMP and cGMP might be sufficient to change cellular permeability (Ohno et al, 1993; Reich et al, 1990; Wegener et al, 1999) even under shear stress (for review, see van Hinsbergh, 1997). However, the detailed signaling mechanisms leading to an increase in TER under shear stress must be determined.

Moderate shear stress-induced changes of TER (not exceeding $20 \%$ ) do not seem sufficient to be a pathogenic risk for the development of vascular impairments such as arteriosclerosis. The constant capacitance serves as an internal control, indicating the absence of large intercellular gap formation. In our hands, shear stress-induced gap formation was only observed when subconfluent cultures were used (data not shown). PSEC cultures are assessed as confluent when the cell density reaches approximately 1.2 to $1.4 \times 10^{3}$ cells/ $\mathrm{mm}^{2}$. Cell cultures that completely cover the culture surface without forming a polygonal cobblestone pattern display cell areas that are two to three times larger than cobblestone-like endothelial cells. These cells characteristically display gap formation under shear stress. Another possibility to get shear stress-induced formation of interendothelial gaps is the presence of disturbed flow profiles. Disturbed shear stress profiles in cell culture models cause disorganization of endothelial integrity by 


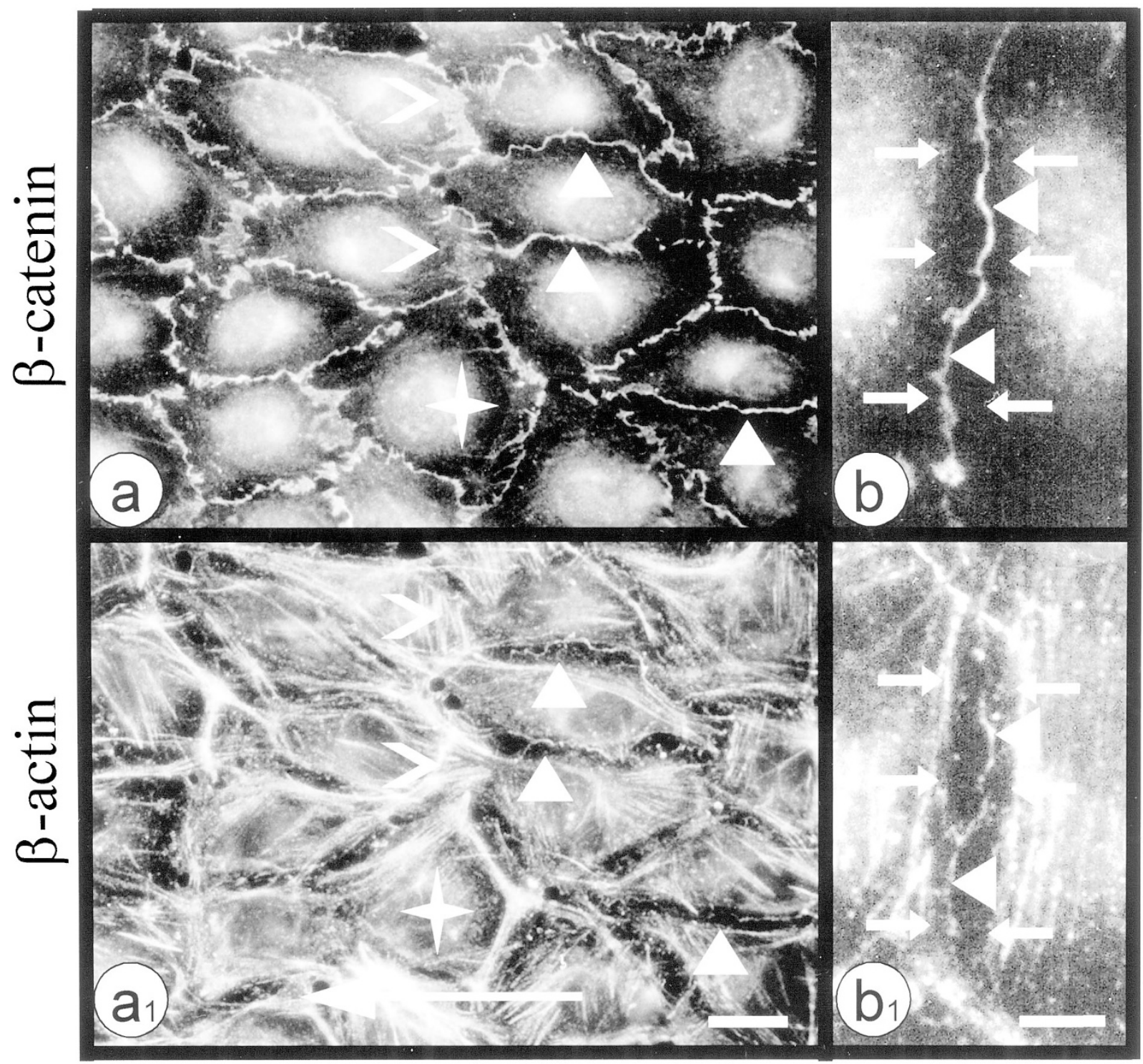

Figure 9.

Endothelial cells exposed to $50 \mathrm{dyn} / \mathrm{cm}^{2}$ for 5 hours. Cells are double-labeled with a polyclonal antibody to $\beta$-catenin $(a, b)$ and a monoclonal antibody to $\beta$-actin $\left(a_{1}, b_{1}\right)$. At areas where small bands of $\beta$-catenin immunofluorescence face the junctions $(a, b), \beta$-actin also shows a reduced fluorescence $\left(a_{1}, b_{1}\right)$. At these areas, stress fibers were absent $\left(b, b_{1}\right.$, arrows). Overlapping cell junctions displaying catenin superstructures are closely related to stress fiber formation ( $a$, $a_{1}$, open arrowheads). Note that stress fibers developed after shear stress $\left(a_{1}\right)$. Bars, $\left(a, a_{1}\right): 25 \mu \mathrm{m} ;\left(b, b_{1}\right): 10 \mu \mathrm{m}$.

gap formation and loss of the cells from the substrate (Davies et al, 1986; DePaola et al, 1992). These and the presented data agree with the development of arteriosclerotic lesions in areas of disturbed but not laminar flow profiles in situ.

\section{Shear Stress-Induced Changes in TER Correlates with Morphodynamics}

The physiologic changes in TER correlate with changes in cellular morphodynamics. As shown in Figure 5, the initial increase in TER was associated with an inhibition of fluctuations (random zigzag movements of the cells that are typically present under resting conditions) (Dieterich et al, 2000). Therefore, the shear stress-induced initial decrease in fluctuations might represent stabilization of cell-to-cell junctions leading to the increase in
TER. The subsequent decrease of the TER occurred after a period of approximately 10 to 20 minutes and was accompanied by a change in the SI showing a shear stress-induced change in cell shape (Fig. 3). We recently reported a heterogeneous cell motility of individual cells within confluent cultures of endothelial cells even in the presence of shear stress (Dieterich et al, 2000). These observations and the presented data suggest that the cell-to-cell adhesion must be weakened before cells can move relative to each other.

\section{Reorganization of Cell-To-Cell Junctions under Shear Stress Is Heterogeneous within Individual Cells in Confluent Cultures}

In vivo tight junctions are thought to be the primary site of permeability control. Yoshida et al (1995) dem- 
onstrated that tight junctions are strongly expressed in endothelial cells that are exposed to high laminar shear stress, but less pronounced in areas with low shear stress. In vitro, under ordinary culture conditions, tight junctions are either poorly developed in macrovascular endothelial cells or are completely lacking (Craig et al, 1998; Yoshida et al, 1995). Recently, an increase in tight junction formation was reported for cultured endothelial cells after 24 to 48 hours of shear stress exposure (Yoshida et al, 1995). However, in the present paper we focussed on early events of shear stress adaptation with respect to monolayer integrity. The influence of shear stressinduced tight junction formation on TER should be the subject of future investigations.

Shear stress-induced morphodynamics of individual cells within confluent cultures is heterogeneous, especially with respect to cell locomotion relative to other cells (Dieterich et al, 2000). This heterogeneity may correspond to the heterogeneous distribution of catenins after shear stress (compare Fig. 7 with Fig. 9). $\beta$-actin was codistributed with $\beta$-catenin and closely associated with the cell borders. Within these subcellular areas, stress fibers were absent. Therefore, we assume that there is migration activity at these subcellular sites. This distribution of $\beta$-actin, close to the junctions within a subcellular stress fiber-free area, is consistent with the concept that $\beta$-actin drives the formation of leading edges, as previously described (Hoock et al, 1991). In contrast, overlapping areas of junctions displayed stress fibers that are assumed to increase cellular adhesion to the substrate and reduced motility at these sides (Hoock et al, 1991). Based on the presented results, we propose that $\beta$-actin also drives leading edge-like plasma membrane protrusions of cells within confluent cultures.

\section{Laminar Shear Stress Does Not Disturb Endothelial Integrity}

Shear stress induces a reorganization of cell-to-cell contacts and of cytoskeletal components. As shown in Figures 7 and 9, this process took place without any visible gap formation between the cells, which indicates a differentiated regulation of the cell-to-cell junctions in culture. In vivo, endothelial cells rest on a basement membrane that supports cell integrity and adhesion more sufficiently than substrates used in culture. Although the presented experiments were performed in a cell culture model, they show that even high levels of laminar shear stress do not markedly disturb endothelial integrity.

Although data exist describing the role of catenins in intercellular adhesion, the regulation is not fully understood. However, $\gamma$-catenin (Fig. 7) seems to play an important role in the maintenance of endothelial integrity during rearrangements of the cell junctions. Inhibition of $\gamma$-catenin synthesis by microinjection of antisense oligonucleotides in cultured human and PSEC produced dramatic dissociations of the junctions under physiologic levels of shear stress but not under resting conditions (Schnittler et al, 1997). Also, tar- geted mutations or knockout of $\gamma$-catenin in mice caused disruption of desmosomes in skin epithelium and myocardium (Bierkamp et al, 1996; Ruiz et al, 1996). These results are consistent with the concept that the presence of $\gamma$-catenin at the junction complex is required to protect the cell layer from hyperpermeability and gap formation during morphologic changes of endothelial cells.

Recently, a shear stress-induced transient gap formation was reported for cultured porcine aortic endothelial cells at $15 \mathrm{dyn} / \mathrm{cm}^{2}$ after 8.5 hours, whereas $\gamma$-catenin was present at the junctions but a loss of $\gamma$-catenin expression was observed after 24 hours. Surprisingly, this loss was not associated with gap formation (Noria et al, 1999). In the present study, we performed online registration of paracellular resistance in the presence of shear stress and a gap formation would be accompanied by a drop in TER. This was not observed within 10 hours but, in contrast, we found a continuous increase in TER after the described TER minimum. The discrepancy between the published data (Noria et al, 1999) and the present data might be based on differences between the cell-types or culture conditions, such as cell density, serum concentration, or the passage number of the investigated culture.

We conclude that shear stress-induced change in TER is largely based on the morphodynamic behavior of the cells. The observed moderate changes in paracellular permeability during transition from low to high shear stress levels seem too small to significantly contribute to the development of vascular impairments by increased paracellular permeability.

\section{Materials and Methods}

\section{Cell Culture}

Endothelial cells derived from pulmonary trunk were isolated and cultured as described elsewhere (Schnittler et al, 1990). Briefly, pulmonary arteries from freshly slaughtered pigs were washed with PBS (Seromed, Berlin, Germany), filled with $0.1 \%$ collagenase (clostridium histolyticum; Boehringer-Mannheim Biochemica, Mannheim, Germany), and incubated for 15 minutes at $37^{\circ} \mathrm{C}$ in a water bath. Endothelial cells were gently washed off from the vessel wall. The collected cells were centrifuged (10 minutes at $200 \times$ g) and washed twice with medium 199. Cells were cultured to confluence in medium 199 supplemented with 10\% FCS (Biochrom, Berlin, Germany), $50 \mathrm{U} / \mathrm{ml}$ of penicillin G (Sigma, Deisenhofen, Germany), and 50 $\mu \mathrm{g} / \mathrm{ml}$ of streptomycin sulfate (Sigma). First or second passage cells were used for the experiments as described.

\section{Rheological In Vitro System}

Shear stress was generated in a cone and plate multi-channel rheological in vitro system that was recently described (Dieterich et al, 2000; Schnittler et al, 1993). Briefly, up to 12 individual measuring chambers can be run in parallel and shear stress between 0 
and $200 \mathrm{dyn} / \mathrm{cm}^{2}$ can be generated. The sheer stress is oriented in a circular direction with a small radial component, which is used for continuous medium exchange. During long time shear stress exposure medium was continuously exchanged via steel capillaries. All experiments were performed in HEPESbuffered M199 supplemented with 10\% heatinactivated FCS, $50 \mathrm{U} / \mathrm{ml}$ of penicillin, $50 \mu \mathrm{g} / \mathrm{ml}$ of streptomycin sulfate, and $3 \%$ polyvinyl-pyrrolidone (MW: $360 \mathrm{kDa}$ ) to increase the dynamic viscosity, $v$, as described elsewhere (Schnittler et al, 1993). The cone has a diameter of $28 \mathrm{~mm}$ and a cone angel of $2.5^{\circ}$. Transparency of the system allows the on-line observation of endothelial cells by phase-contrast microscopy and time-lapse recording using a video camera. Pictures were taken every 60 seconds.

Thus, manipulated and control cells of the same passage can be investigated at different levels of shear stress at the same times. Determination of cell motility and the cell shape as a function of time (morphodynamics) was performed using self-written image analyses software as described recently in detail (Dieterich et al, 2000).

Briefly, the image analyses software delivers segmentations of the cells consisting of the cell nucleus and perinuclear organelles, which display high contrast in the time-lapse recordings and typically have areas of approximately $50 \%$ of the total cell area. The overall SI describes the cell form and is defined by:

$$
\langle S I(t)\rangle=\frac{1}{N} \sum_{i=1}^{N} \frac{4 \pi A_{i}(t)}{P_{i}^{2}(t)}
$$

where $\mathrm{A}$ is the area, $\mathrm{P}$ the perimeter, and $\mathrm{N}$ the number of segments for the time point $t$.

The fluctuations, $\xi$, describe the zigzag movements of cells around the mean locomotion trajectories (Dieterich et al, 2000).

\section{Impedance Analysis under Shear Stress}

Glass slides used for impedance spectroscopy were manufactured in a perfectly parallel manner with a diameter of $4.5 \mathrm{~cm}$. Using a mask with appropriate geometry, thin gold electrodes were evaporated at $10^{-5}$ torr on the glass slide (Fig. 1). To improve gold adhesion to the glass substrate, a thin chromium layer $(50 \mathrm{~nm})$ was previously evaporated in the same layout according to Wegener et al (1999). The electrode arrangement consisted of three small, independent working electrodes $\left(0.05 \mathrm{~cm}^{2}\right.$ each) and one largesized counter electrode $\left(6 \mathrm{~cm}^{2}\right)$. The electrode thickness was approximately $150 \mathrm{~nm}$ as determined by atomic force microscopy. Because of the large differences in the electrode areas between the measuring electrodes and the counter electrode, the impedance contribution of the counter electrode can be neglected. An inert ring (nontoxic polymethylmetaacrylate) was glued onto the culture glass plate using a noncytotoxic silicon (Elchsiegel, Rhône poulenc, Leverkusen, Germany) to separate the measuring area within the shear space, which is filled with culture medium, from the contact area. To contact the electrodes, short cables were soldered to the peripheral gold areas outside the ring. To acquire impedance spectra from up to nine individual rheological units having three measuring electrodes each, a relay was developed to connect the counter and one of the three working electrodes to an impedance spectrometer (SI-1260A, Solartron Instruments, Farnborough, United Kingdom). Thus, three independent measuring areas within each individual unit were analyzed.

To control relay and impedance spectrometer, we developed and implemented software based on the visual programming language LabVIEW (National Instruments, München, Germany). The program acquired the data and analyzed the impedance spectra. The impedance magnitude $|Z|$ was determined as a function of frequency between $10 \mathrm{~Hz}$ and $1 \mathrm{MHz}$. Each spectrum was analyzed by fitting the parameters of an equivalent circuit (Fig. 2) to the experimental data using the Levenberg-Marquardt algorithm (proportional weighting) (Press et al, 1992). The equivalent circuit used for data analysis has been described recently. The equivalent model delivers electrode parameters, the ohmic resistance of the medium $R_{\text {bulk }}$, the capacitance of the plasma membranes, and the TER (Wegener et al, 1999). Data acquisition and analysis of a spectrum consisting of 50 individual frequencies requires approximately 1 minute. Spectra were sequentially recorded from different individual rheological units containing three measuring electrodes each. Typical spectra are shown in Figure 2.

\section{Antibodies}

A polyclonal rabbit antibody, which cross-reacts with the cytoplasmic (C-terminal) domain of classical cadherins (pan-cadherin antibody) and with $\beta$-actin was purchased from Sigma. Monoclonal antibodies to VEcadherin, $\alpha$-catenin, $\beta$-catenin, and $\gamma$-catenin were purchased from Transduction Laboratories (Lexington, Kentucky). A polyclonal $\beta$-catenin antibody was raised in rabbits against a peptide covering the last 21 C-terminal amino acids of $\beta$-catenin. FITC- or TRITCconjugated secondary antibodies were purchased from Dianova (Hamburg, Germany).

\section{Immunocytochemistry}

Cells were fixed with $2 \%$ formaldehyde and incubated with the appropriate primary and secondary antibodies, as described above. After several washes with PBS (15 minutes), the coverslips were mounted on glass slides covered with $60 \%$ glycerol and $1.5 \%$ n-propylgallate as an antifading substance. For double-immunofluorescence cytochemistry (simultaneous localization of $\gamma$-catenin and $\beta$-catenin or $\beta$-catenin and $\beta$-actin), the respective monoclonal antibody was mixed with the polyclonal rabbit $\beta$-catenin antibody. After incubation with this antibody mixture for 2 hours and subsequent washes with PBS, cell monolayers were incubated for 30 minutes with a 
mixture of FITC-labeled goat-anti-mouse IgG and TRITC-labeled goat-anti-rabbit lgG.

\section{Acknowledgements}

The excellent technical assistance of Anne Horstkötter is greatly acknowledged. We also thank Ludger Sasse for competent electronic work.

\section{References}

Ayalon O, Sabanai H, Lampugnani MG, Dejana E, and Geiger B (1994). Spatial and temporal relationships between cadherins and PECAM-1 in cell-cell junctions of human endothelial cells. J Cell Biol 126:247-258.

Bierkamp C, McLaughlin KJ, Schwarz H, Huber O, and Kemler R (1996). Embryonic heart and skin defects in mice lacking plakoglobin. Dev Biol 180:780-785.

Burnstock G (1999). Release of vasoactive substances from endothelial cells by shear stress and purinergic mechanosensory transduction. J Anat 194:335-342.

Caro CG, Fitz-Gerald JM, and Schroter RC (1969). Arterial wall shear and distribution of early atheroma in man. Nature 223:1159-1160.

Caro CG and Nerem RM (1973). Transport of 14C-4cholesterol between serum and wall in the perfused dog common carotid artery. Circ Res 32:187-205.

Cole KS (1972). Membranes, ions and impulses. Berkeley: University of California Press.

Craig LE, Spelman JP, Strandberg JD, and Zink MC (1998). Endothelial cells from diverse tissues exhibit differences in growth and morphology. Microvasc Res 55:65-76.

Davies PF, Remuzzi A, Gordon EJ, Dewey CF Jr, and Gimbrone MA Jr (1986). Turbulent fluid shear stress induces vascular endothelial cell turnover in vitro. Proc Natl Acad Sci U S A 83:2114-2117.

De Chastonay C, Gabbiani G, Elemer G, and Huttner I (1983). Remodeling of the rat aortic endothelial layer during experimental hypertension. Changes in replication rate, cell density, and surface morphology. Lab Invest 48:45-52.

Dejana E (1996). Endothelial adherens junctions: Implications in the control of vascular permeability and angiogenesis. $\mathrm{J}$ Clin Invest 98:1949-1953.

Dejana E (1997). Endothelial adherens junctions: Implications in the control of vascular permeability and angiogenesis. J Clin Invest 100:S7-S10.

Dejana E, Bazzoni G, and Lampugnani MG (1999). Vascular endothelial (VE)-cadherin: Only an intercellular glue? Exp Cell Res 252:13-19.

DePaola N, Gimbrone MA Jr, Davies PF, and Dewey CF Jr (1992). Vascular endothelium responds to fluid shear stress gradients [published erratum appears in Arterioscler Thromb 13:465]. Arterioscler Thromb 12:1254-1257.

Dewey CF Jr, Bussolari SR, Gimbrone MA Jr, and Davies PF (1981). The dynamic response of vascular endothelial cells to fluid shear stress. J Biomech Eng 103:177-185.

Dieterich P, Odenthal-Schnittler M, Mrowietz C, Krämer M, Sasse L, Oberleithner H, and Schnittler HJ (2000). Quantitative morphodynamics of endothelial cells within confluent cultures in response to fluid shear stress. Biophys J 79:12851297.

Eskin SG, Ives CL, McIntire LV, and Navarro LT (1984). Response of cultured endothelial cells to steady flow. Microvasc Res 28:87-94.

Flaherty JT, Pierce JE, Ferrans VJ, Patel DJ, Tucker WK, and Fry DL (1972). Endothelial nuclear patterns in the canine arterial tree with particular reference to hemodynamic events. Circ Res 30:23-33.

Franke RP, Grafe M, Schnittler H, Seiffge D, Mittermayer C, and Drenckhahn D (1984). Induction of human vascular endothelial stress fibres by fluid shear stress. Nature 307 : 648-649.

Franke WW, Cowin P, Grund C, Kuhn C, and Kapprell HP (1988). The endothelial junction: The plaque and its components. New York: Plenum Publishing Corp, 147-166.

Gabbiani G, Gabbiani F, Lombardi D, and Schwartz SM (1983). Organization of actin cytoskeleton in normal and regenerating arterial endothelial cells. Proc Natl Acad Sci U S A 80:2361-2364.

Geyer H, Geyer R, Odenthal-Schnittler M, and Schnittler HJ (1999). Characterization of human vascular endothelial cadherin glycans. Glycobiology 9:915-925.

Giaever I and Keese CR (1984). Monitoring fibroblast behavior in tissue culture with an applied electric field. Proc Natl Acad Sci U S A 81:3761-3764.

Giaever I and Keese CR (1991). Micromotion of mammalian cells measured electrically [published erratum appears in Proc Natl Acad Sci U S A 90:1634]. Proc Natl Acad Sci U S A 88:7896-7900.

Hoheisel D, Nitz T, Franke H, Wegener J, Hakvoort A, Tilling T, and Galla HJ (1998). Hydrocortisone reinforces the bloodbrain properties in a serum free cell culture system [corrected and republished article originally printed in Biochem Biophys Res Commun 244:312-6]. Biochem Biophys Res Commun 247:312-315.

Hoock TC, Newcomb PM, and Herman IM (1991). Beta actin and its mRNA are localized at the plasma membrane and the regions of moving cytoplasm during the cellular response to injury. J Cell Biol 112:653-664.

Janshoff A, Wegener J, Sieber M, and Galla HJ (1996). Double-mode impedance analysis of epithelial cell monolayers cultured on shear wave resonators. Eur Biophys J 25:93103.

Knudsen KA, Soler AP, Johnson KR, and Wheelock MJ (1995). Interaction of alpha-actinin with the cadherin/catenin cell-cell adhesion complex via alpha-catenin. J Cell Biol 130:67-77.

Ku DN, Giddens DP, Zarins CK, and Glagov S (1985). Pulsatile flow and atherosclerosis in the human carotid bifurcation. Positive correlation between plaque location and low oscillating shear stress. Arteriosclerosis 5:293-302.

Lampugnani MG, Corada M, Caveda L, Breviario F, Ayalon O, Geiger B, and Dejana E (1995). The molecular organization of endothelial cell to cell junctions: Differential association of plakoglobin, beta-catenin, and alpha-catenin with vascular endothelial cadherin (VE-cadherin). J Cell Biol 129:203-217.

Lampugnani MG and Dejana E (1997). Interendothelial junctions: Structure, signalling and functional roles. Curr Opin Cell Biol 9:674-682. 
Langille BL and Adamson SL (1981). Relationship between blood flow direction and endothelial cell orientation at arterial branch sites in rabbits and mice. Circ Res 48:481-488.

Levesque MJ, Liepsch D, Moravec S, and Nerem RM (1986). Correlation of endothelial cell shape and wall shear stress in a stenosed dog aorta. Arteriosclerosis 6:220-229.

Levesque MJ and Nerem RM (1985). The elongation and orientation of cultured endothelial cells in response to shear stress. J Biomech Eng 107:341-347.

Navarro P, Caveda L, Breviario F, Mandoteanu I, Lampugnani MG, and Dejana E (1995). Catenin-dependent and -independent functions of vascular endothelial cadherin. J Biol Chem 270:30965-30972.

Nerem RM (1992). Vascular fluid mechanics, the arterial wall, and atherosclerosis. J Biomech Eng 114:274-282.

Noll T, Holschermann H, Koprek K, Gunduz D, Haberbosch W, Tillmanns H, and Piper HM (1999). ATP reduces macromolecule permeability of endothelial monolayers despite increasing $\left[\mathrm{Ca}^{2+}\right]_{\mathrm{i}}$. Am J Physiol 276:H1892-H1901.

Noria S, Cowan DB, Gotlieb Al, and Langille BL (1999). Transient and steady-state effects of shear stress on endothelial cell adherens junctions. Circ Res 85:504-514.

Ohno M, Gibbons GH, Dzau VJ, and Cooke JP (1993). Shear stress elevates endothelial cGMP. Role of a potassium channel and G protein coupling. Circulation 88:193-197.

Okano M and Yoshida Y (1993). Influence of shear stress on endothelial cell shapes and junction complexes at flow dividers of aortic bifurcations in cholesterol-fed rabbits. Front Med Biol Eng 5:95-120.

Ozawa M and Kemler R (1998). Altered cell adhesion activity by pervanadate due to the dissociation of alpha-catenin from the E-cadherin.catenin complex. J Biol Chem 273:6166-6170.

Press WH, Teukolsky SA, Vetterling WT, and Flannery BP (1992). Numerical Recipes. Cambridge: Cambridge University Press.

Reich KM, Gay CV, and Frangos JA (1990). Fluid shear stress as a mediator of osteoblast cyclic adenosine monophosphate production. J Cell Physiol 143:100-104.

Remuzzi A, Dewey CF Jr, Davies PF, and Gimbrone MA Jr (1984). Orientation of endothelial cells in shear fields in vitro. Biorheology 21:617-630.

Rimm DL, Koslov ER, Kebriaei P, Cianci CD, and Morrow JS (1995). Alpha 1(E)-catenin is an actin-binding and -bundling protein mediating the attachment of F-actin to the membrane adhesion complex. Proc Natl Acad Sci U S A 92:8813-8817.

Ruiz P, Brinkmann V, Ledermann B, Behrend M, Grund C, Thalhammer C, Vogel F, Birchmeier C, Gunthert U, Franke WW, and Birchmeier W (1996). Targeted mutation of plakoglobin in mice reveals essential functions of desmosomes in the embryonic heart. J Cell Biol 135:215-225.

Schnittler HJ and Feldmann H (1999). Molecular pathogenesis of filovirus infections: Role of macrophages and endothelial cells. Curr Top Microbiol Immunol 235:175-204.

Schnittler HJ, Franke RP, Akbay U, Mrowietz C, and Drenckhahn D (1993). Improved in vitro rheological system for studying the effect of fluid shear stress on cultured cells. Am J Physiol 265:C289-C298.

Schnittler H, Franke RP, and Drenckhahn D (1989). Role of the endothelial actin filament cytoskeleton in rheology and permeability. Z Kardiol 78:1-4.
Schnittler HJ, Puschel B, and Drenckhahn D (1997). Role of cadherins and plakoglobin in interendothelial adhesion under resting conditions and shear stress. Am J Physiol 273: H2396-H2405.

Schnittler HJ, Schmandra T, and Drenckhahn D (1998). Correlation of endothelial vimentin content with hemodynamic parameters. Histochem Cell Biol 110:161-167.

Schnittler HJ, Wilke A, Gress T, Suttorp N, and Drenckhahn D (1990). Role of actin and myosin in the control of paracellular permeability in pig, rat and human vascular endothelium. J Physiol (Lond) 431:379-401.

Shen J, Gimbrone MA Jr, Luscinskas FW, and Dewey CF Jr (1993). Regulation of adenine nucleotide concentration at endothelium-fluid interface by viscous shear flow. Biophys $\mathrm{J}$ 64:1323-1330.

Shen J, Luscinskas FW, Connolly A, Dewey CF Jr, and Gimbrone MA Jr (1992). Fluid shear stress modulates cytosolic free calcium in vascular endothelial cells. Am J Physiol 262:C384-C390.

Suttorp N, Hippenstiel S, Fuhrmann M, Krull M, and Podzuweit T (1996). Role of nitric oxide and phosphodiesterase isoenzyme II for reduction of endothelial hyperpermeability. Am J Physiol 270:C778-C785.

van Hinsbergh WM (1997). Endothelial permeability for macromolecules. Mechanistic aspects of pathophysiological modulation. Arterioscler Thromb Vasc Biol 17:1018-1023.

Waters CM (1996). Flow-induced modulation of the permeability of endothelial cells cultured on microcarrier beads. J Cell Physiol 168:403-411.

Waters CM, Glucksberg MR, Depaola N, Chang J, and Grotberg JB (1996). Shear stress alters pleural mesothelial cell permeability in culture. J Appl Physiol 81:448-458.

Wegener J, Sieber M, and Galla HJ (1996). Impedance analysis of epithelial and endothelial cell monolayers cultured on gold surfaces. J Biochem Biophys Methods 32:151-170.

Wegener J, Zink S, Rosen P, and Galla H (1999). Use of electrochemical impedance measurements to monitor betaadrenergic stimulation of bovine aortic endothelial cells. Pflugers Arch 437:925-934.

Wong AJ, Pollard TD, and Herman IM (1983). Actin filament stress fibers in vascular endothelial cells in vivo. Science 219:867-869.

Yap AS, Brieher WM, and Gumbiner BM (1997). Molecular and functional analysis of cadherin-based adherens junctions. Annu Rev Cell Dev Biol 13:119-146.

Yoshida Y, Okano M, Wang S, Kobayashi M, Kawasumi M, Hagiwara H, and Mitsumata M (1995). Hemodynamic-forceinduced difference of interendothelial junctional complexes. Ann N Y Acad Sci 748:104-120; discussion 121.

Yoshida K and Sugimoto K (1996). Morphological and cytoskeletal changes in endothelial cells of vein grafts under arterial hemodynamic conditions in vivo. J Electron Microsc (Tokyo) 45:428-435.

Yuan Y, Granger HJ, Zawieja DC, and Chilian WM (1992). Flow modulates coronary venular permeability by a nitric oxide-related mechanism. Am J Physiol 263:H641-H646. 